\title{
Khuff Sequence KS4: High-resolution Anatomy of a Middle Khuff Grainstone Package, Oman Mountains, Sultanate of Oman
}

\author{
Marlene Haase (University of Tübingen $<$ mmlhaase@googlemail.com>), Thomas Aigner \\ (University of Tübingen) and Holger Forke (Museum of Natural History, Berlin)
}

This outcrop study is part of a larger-scale project on the Saiq Formation in the Oman Mountains (outcrop analog of Khuff Formation), and focussed on the small-scale heterogeneities of the lower part of Khuff Sequence 4 (KS4). This interval is dominated by massive grainstones that at first glance seem extremely homogenous with distinct trough cross-bedding detectable in spite of strong dolomitization. Serrated gamma-ray patterns made small-scale cycle interpretations difficult. Therefore a very detailed facies and sequence analysis was necessary to decipher the vertical microfacies make-up of the grainstones and link it with potential pore types.

\section{Methods}

Three KS4 sections of around $70 \mathrm{~m}$ were logged with a high-resolution scale of 1:50. Lithology, Dunham texture, components and sedimentary structures were logged. Extensive microfacies analyses of 145 thin-sections sampled every $1.5 \mathrm{~m}$ on average throughout the lower part of the KS4 was carried out. Gamma-ray measurements were conducted every 0.25 $\mathrm{m}$ with a measurement period of 15 seconds. The detailed one dimensional data analysis reflected here will be followed by two dimensional correlations. Finally a three dimensional exploration-scale model will be constructed.

\section{Sedimentological Analysis}

The detailed logging enabled the interpretation of a smaller scale of cyclicity compared to those of previous studies. These are termed "small-scale cycles". Small-scale cycles are stacked into fifth- and fourth-order cycles. These are nested within the overall third-oder transgressive-regressive cycle of the KS4. As minor microfacies changes were difficult to make out in the outcrop due to strong and multiple dolomitization processes, thin-section analysis was crucial.

\section{Biofacies}

To fully understand small-scale depositional environment changes biofacies criteria in the thin-section were recorded. To differentiate between back or foreshoal deposition foraminifera, algae and metazoan species found were grouped into the environmental settings they are characteristic of. For instance: increased occurence of the dasycladacean algae Mizzia indicates restrictive, intraplatform deposition. Predominant gymnocodiacean algae such as Gymnocodium or Permacalculus represent foreshoal deposits.

\section{Conclusions}

The grainstone package in Khuff Sequence 4 (KS 4) displays a highly differentiated internal anatomy. Mini-cycles and variable microfacies type changes result in a heterogeneous buildup of grainstones. The cyclicities within grainstone complexes indicate minor changes in depositional environments. This has a direct effect on the dominant grain types, which in turn affects the potential pore types. Pore types in the KS4 are therefore likely to vary: oomoldic versus interparticle versus intraparticle; this has a profound influence on permeability. 


\section{EAGE}

Vertical microfacies variance could therefore account for differing production rates in KS4 grainstones.

\section{References}

Koehrer, B., M. Zeller, T. Aigner, M. Poeppelreiter, P. Milroy, H. Forke and S. Al-Kindi 2010. Facies and stratigraphic framework of a Khuff outcrop equivalent: Saiq and Mahil formations, Al Jabal al-Akhdar, Sultanate of Oman. GeoArabia, v. 15, no. 2, p. 91-156.

Koehrer, B., T. Aigner and M. Poeppelreiter 2011. Field-scale geometries of Upper Khuff reservoir geobodies in an outcrop analogue (Oman Mountains, Sultanate of Oman). Petroleum Geoscience, v. 17, no. 1, p. 3-16. 


\section{EAGE}

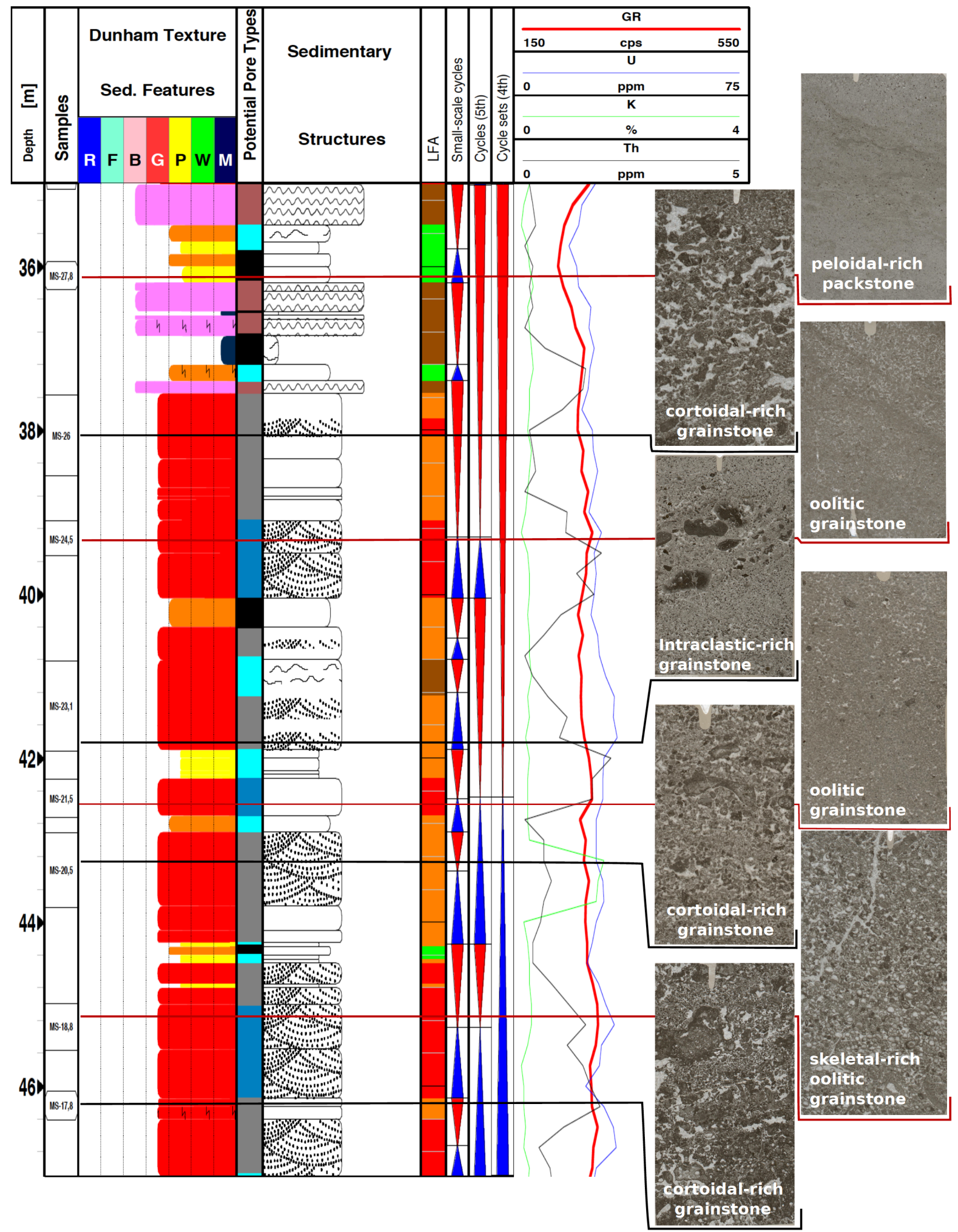

Figure 1: Example high-resolution $\log$ of a ca. $10 \mathrm{~m}$ thick grainstone-dominated package (one cycle set) in the lower KS4 in Wadi Sahtan, illustrating highly differentiated internal anatomy and an additional, smaller scale of cycles. To the right thin-sections are shown. The sampled grainstone composition ranges from cortoidal-, peloidal- and skeletal-rich to pure oolitic. 